J. Perinat. Med. 17 (1989) 271

\section{Plasma vasopressin, renin and catecholamines during nitroprusside- induced hypotension in the newborn lamb}

\author{
Alan B. Zubrow', Salha S. Daniel ${ }^{2}$, Raymond I. Stark², M. Kazim Husain', and \\ L. Stanley James ${ }^{2}$ \\ ${ }^{1}$ The Medical College of Pediatrics, Philadelphia, Pennsylvania, U.S.A. \\ ${ }^{2}$ Departments of Pediatrics and Anesthesiology, College of Physicians and Sur- \\ geons, Columbia University, Babies Hospital, New York, N.Y. U.S.A.
}

\section{Introduction}

The newborn may become hypotensive during episodes of sepsis, acidosis, respiratory distress, hypovolemia, hemorrhage, heart failure, abdominal catastrophe, or active intracranial hemorrhage. A rebound hypertension may occur during the recovery period.

The fetus and neonate respond to experimantal hypovolemia or hypotension with increased release of vasoactive mediators in a similar fashion to the adult $[10,16,21,22,24,39,40]$. The recovery of the fetus from nitroprusside induced hypotension, is associated with prolonged high levels of vasoactive mediators and a rebound hypertension that is longer than that observed in the adults $[39,40]$. The present experiments were designed to investigate a possible mechanism for this difference by examining the simultaneous response of the neurohypophyseal, sympathetic and renin-angiotensin systems and the pattern of recovery of the newborn from nitroprusside induced hypotension in comparison to the fetus and adult.

\section{Material and methods}

A femoral artery and vein were catheterized in six lambs 1-2 days old following light sedation with $1 \mathrm{mg} / \mathrm{kg}$ phencyclidine intramuscularly and local infiltration of $5 \mathrm{mg}$ xylocaine as described previously [6]. Experiments were performed at least one day following the placement of catheters at a mean of $5.3 \pm 0.5$ days (range $4-7$

\section{Curriculum vitae}

Alan B. Zubrow, M.D., was born in Philadelphia, PA in 1950. He graduated college (1972) and medical school (1976) from the University of Pennsylvania. His pediatric residency was at the Children's Hospital of Philadelphia, followed by a Neonatal Perinatal Medicine fellowship at

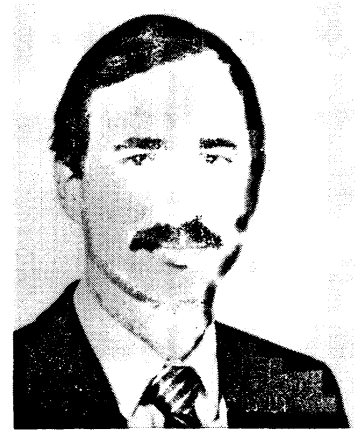

Babies Hospital, Columbia University. He is currently on the staff of the Medical College of Pennsylvania. His main field of interest is perinatal physiology.

days). During the experiments the lambs were lying quietly on their side wrapped lightly and restrained loosely. After a 30-60 minute control period of stable blood pressure and heart rate measurements, freshly prepared sodium nitroprusside $^{1}\left(0.33 \mathrm{mg} \cdot \mathrm{ml}^{-1}\right.$ in $0.9 \%$ saline $)$ was infused intravenously into the lamb for one hour. The infusion rate was adjusted to maintain a mean blood pressure $10-20 \%$ below the control values. The mean total dose of nitroprusside necessary to achieve the desired degree of hypotension was $0.739 \pm 0.274 \mathrm{mg} \cdot \mathrm{kg}^{-1}$ (range 0.312 to $2.075 \mathrm{mg} \cdot \mathrm{kg}^{-1}$ ) or $12 \mathrm{~g} \cdot \mathrm{kg}^{-1} \cdot \mathrm{min}^{-1}$.

${ }^{1}$ (Nipride, Hoffman LaRoche, Inc.) 
This is well below the minimum dose reported to produce toxic side effects [31, 37]. Monitoring was continued for an additional hour after discontinuation of the infusion.

\subsection{Measurements}

Arterial blood pressure was measured using a Stratham transducer $(23 \mathrm{Db})$ and heart rate determined by a cardiotachometer triggered by the pulse pressure. Measurements were recorded on a multichannel Beckman polygraph. Arterial blood samples were taken before $(0 \mathrm{~min})$, during (30 and $60 \mathrm{~min}$ ) and following $(90 \mathrm{~min})$ the nitroprusside infusion. A total of $25 \mathrm{ml}$ of blood $\left(6 \mathrm{ml} \cdot \mathrm{kg}^{-1}\right)$ per study was withdrawn and acutely replaced with normal saline. Blood samples for assay of vasopressin and renin activity were collected in chilled glass tubes containing EDTA, catecholamine levels in chilled tubes containing EGTA and glutathione, and $\mathrm{pH}$, blood gases, sodium and osmolality determination in a heparinized syringe as described previously [40]. The volume of blood withdrawn over the two hour period of these experiments has been shown not to affect vasopressin levels [36].

Plasma was separated by centrifugation (2000 x g; $15 \mathrm{~min} ; 4^{\circ} \mathrm{C}$ and was stored at $-30^{\circ} \mathrm{C}$ for later determination of plasma renin activity, catecholamine, vasopressin, electrolytes and osmolality. Blood $\mathrm{pH}$ and gas tensions were measured immediately using microelectrodes and a Radiometer blood gas monitor.

Renin activity was measured by generation of angiotensin I using New England Nuclear $^{\mathrm{R}}$ Rianen ${ }^{\mathrm{TM}}$ Angiotensin I [ $\left.{ }^{125} \mathrm{I}\right]$ Radio-immunoassay Kit [34]. Epinephrine and norepinephrine were measured by a radioenzymatic method using Upjohn's Cat-A-Kit ${ }^{\mathrm{TM}}$ [25]. Vasopressin was determined by radioimmunoassay using a specific antibody after extraction with acetone and petroleum ether as has been previously described [12].

Plasma sodium and osmolality were measured using an Instrumentation Laboratories Flame Photometer and an Advanced Instrument HiPrecision Research Osmometer respectively. The coefficients of variation of the methods for determination of sodium concentration and osmolality were $\pm 1 \%$ and $\pm 2 \%$ respectively.

\subsection{Statistical analysis}

All data are expressed as mean \pm standard error. The data were analyzed using one way analysis of variance and tested for significance using the Bonferoni method. All $\mathrm{p}$ values listed for vasopressin, renin activity and catecholamines represent analysis using a log transformation.

\section{Results}

The rate of sodium nitroprusside infusion was adjusted to achieve a decrease in mean blood pressure of $10-20 \%(6-13 \mathrm{mmHg})(\mathrm{p}<.02)$ (figure 1). Mean blood pressure values during the first $2 \mathrm{~min}$ of hypotension fell even lower than $20 \%$ (from 67 to $35 \mathrm{mmHg}$ ) until the infusion rate could be adjusted correctly. After the end of the infusion, mean blood pressure increased significantly (up to $76 \mathrm{mmHg}$ ) and remained elevated for $20 \mathrm{~min}(\mathrm{p}<.05)$. Except for one time epoch, after cessation of the infusion when it fell from 200 to $160 \mathrm{bpm}$, the heart rate remained statistically unchanged from the control period.

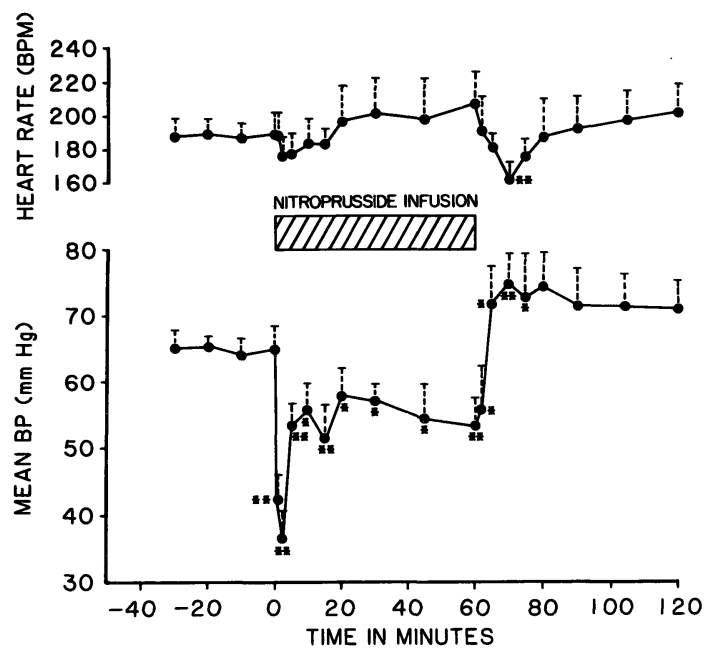

Figure 1. Changes in heart rate (upper portion) and mean blood pressure (lower portion) before, during, and following maternal nitroprusside infusion (as indicated). Data expressed as mean $\pm \mathrm{SE}$.

$\left({ }^{*} \mathrm{p}<.05,{ }^{* *} \mathrm{p}<.01\right)$.

Vasoactive mediator data are shown in figure 2. Vasopressin concentration increased maximally from $2.4 \pm 0.57 \mathrm{pg} \cdot \mathrm{ml}^{-1}$ to $35.1 \pm 16.28 \mathrm{pg}$ 


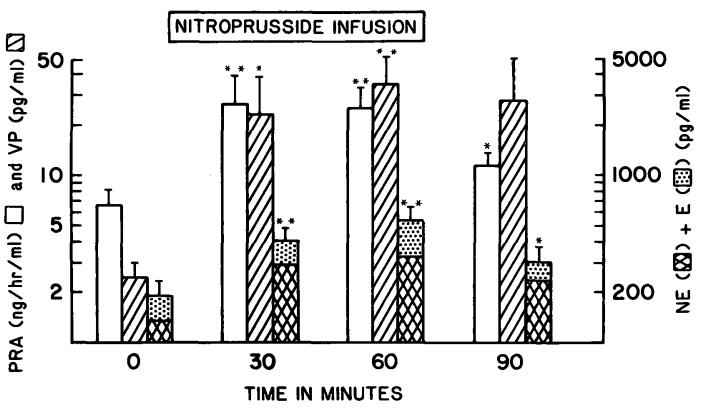

Figure 2. Changes in vasoactive mediators before, during and following neonatal hypoten: plasma renin activity (PRA, $\mathrm{ng} \cdot \mathrm{ml}^{-1} \cdot \mathrm{hr}^{-1}$ ) (clear bar), vasopressin $\left(\mathrm{VP}, \mathrm{pg} \cdot \mathrm{ml}^{-1}\right.$ ) (composed of norepinephrine, $\mathrm{NE}$, hatched lower portion of bar and epinephrine, E, stippled upper portion of bar). Data expressed as mean $\pm \mathrm{SE}$.

$(* \mathrm{p}<.05, * * \mathrm{p}<.01)$

$\cdot \mathrm{ml}^{-1}(\mathrm{p}<.002)$ after $60 \mathrm{~min}$ of hypotension. Maximal increases of plasma renin activity occurred at $30 \mathrm{~min}$ (from $6.7 \pm 1.56$ to 27.4 $\left.\pm 11.44 \mathrm{ng} \cdot \mathrm{ml}^{-1} \cdot \mathrm{h}^{-1}, \mathrm{p}<.003\right)$. Epinephrine $\left(55.8 \pm 21.05\right.$ to $206.5 \pm 52.43 \mathrm{pg} \cdot \mathrm{ml}^{-1}$, $\mathrm{p}<.003)$, norepinephrine $(133.5 \pm 33.01$ to $\left.327.8 \pm 52.46 \mathrm{pg} \cdot \mathrm{ml}^{-1}, \mathrm{p}<.003\right)$, and total catecholamines $(189.3 \pm 42.15$ to 534.3 $\left.\pm 100.52 \mathrm{pg} \cdot \mathrm{ml}^{-1}, \mathrm{p}<.0001\right)$ all had their maximal increase at $60 \mathrm{~min}$. Thirty minutes after discontinuing the nitroprusside infusion, the plasma renin activity $\left(11.4 \pm 1.96 \mathrm{ng} \cdot \mathrm{h}^{-1}\right.$, $\mathrm{p}<.02)$, norepinephrine $(233.2 \pm 53.89 \mathrm{pg}$ $\left.\cdot \mathrm{ml}^{-1}, \mathrm{p}<.04\right)$ and total catecholamine level $\left(300.6 \pm 65.92 \mathrm{pg} \cdot \mathrm{ml}^{-1}, \mathrm{p}<.02\right)$ remained statistically higher than control values. Vasopressin levels also remained elevated at a mean of 27.0 $\mathrm{pg} / \mathrm{ml}$; however, this value was not statistically different from control because of wide scatter in the individual levels.
There were no statistically significant differences in mean blood $\mathrm{pH}$ or blood gas tensions (table I). The mean control plasma sodium (141.8 $\pm 1.74 \mathrm{meq} \cdot 1^{-1}$ ) remained unchanged during the experiment and was within the normal range for newborn lambs. The osmolality remained statistically unchanged but did all from 311.4 \pm 2.76 to $303.6 \pm 4.9 \mathrm{mOsm} \cdot \mathrm{kg}^{-1}$ at $120 \mathrm{~min}$. Hct fell from $30.5 \pm 0.49$ to $28.0 \pm 0.94$ at the end of infusion but returned to control levels after 30 minutes.

\section{Discussion}

The present experiments have shown that as in hemorrhagic hypotension, the newborn lamb responds to nitroprusside-induced, euvolemic hypotension by releasing vasopressin, renin and catecholamines. Recovery from hypotension was associated with elevated levels of renin and catecholamines and a prolonged rebound hypertension that was of somewhat shorter duration than in the fetus of the same species (figures 1 and 2).

In agreement with the results of Rose et al, the dose of nitroprusside required by the newborn lamb, to produce a $10-20 \%$ reduction in blood pressure, was slightly higher than in the adults $[27,39]$. Except for a transient bradycardia following the end of the infusion, the nitroprusside induced hypotension in the present experiments was not associated with significant change in heart rate. These results are in agreement with those of Rose et al and KUIPERS et al, in the newborn lamb but not with those of Ross et al in the fetal lambs where a tachycardia was observed $[20,27,30]$. These differences could be due to differences in rates of infusion, age of the lambs and to the negative chronotropic effects of high levels of vasopressin found in RosE's and our experiments but not in those of Ross [23, $27,30]$.

Table I. pH, $\mathrm{PCO}_{2}, \mathrm{PO}_{2}, \mathrm{Na}$, osmolality and $\mathrm{Hct}$ before (Control), after sixty minutes (hypotension), and following the termination of nitroprusside infusion (recovery)

\begin{tabular}{lccc}
\hline & Control & Hypotension & Recovery \\
\hline $\mathrm{pH}$ & $7.41 \pm .011$ & $7.41 \pm .011$ & $7.39 \pm .011$ \\
$\mathrm{PCO}_{2}(\mathrm{mmHg})$ & $38.0 \pm 1.3$ & $38.0 \pm 1.3$ & $37.8 \pm 1.2$ \\
$\mathrm{PO}_{2}(\mathrm{mmHg})$ & $83.5 \pm 4.0$ & $83.5 \pm 4.0$ & $89.7 \pm 3.8$ \\
$\mathrm{Na}(\mathrm{mEq} / \mathrm{L})$ & $141.8 \pm 1.7$ & $142.0 \pm 2.1$ & $145.6 \pm 2.2$ \\
$\mathrm{Osm}(\mathrm{mOsm} / \mathrm{Kg})$ & $311.4 \pm 2.8$ & $308.8 \pm 6.4$ & $303.6 \pm 4.9$ \\
$\mathrm{Hct}(\%)$ & $30.5 \pm 0.49$ & $28.0 \pm 0.94$ & $29.7 \pm 0.87$ \\
\hline
\end{tabular}


During nitroprusside induced hypotension, plasma levels of vasopressin of the newborn lamb rose 15 fold, plasma renin activity 4 fold and catecholamines 3 fold (figure 2). Since nitroprusside reduced mesenteric and renal blood flows, the high levels of VP, PRA and CA could be in part due to a reduction in their rates of elimination $[20,30,38]$. However the rate of rise in the levels suggest that this more likely is due to stimulation of the neurohypophyseal, sympatho adrenal and renin-angiotensin systems in order to maintain blood pressure $[2,8,10,11$, $13,17,29,32]$. Since neither $\mathrm{pHa}, \mathrm{PaO}_{2}$, plasma sodium or osmolality were significantly affected by nitroprusside, hypoxia and hemoconcentration can be ruled out as possible causes for the release of these vasoactive mediators $[4,5,7,26$, 32].

Gavras suggests that in the adult, the sympathetic nervous system is more involved in the maintenance of blood pressure whereas vasopressin and renin are important back-up mechanisms [9]. The increase in vasopressin in the present experiments was lower, while that of PRA was higher and catecholamines similar to those found in the ewe during a comparable degree of nitroprusside induced hypotension [39]. From our results and those of Rose et al [29], it is tempting to postulate that in the newborn it is the renin-angiotensin system that is more important. However, in addition to their direct effects, vasopressin, renin-angiotensin and catecholamines interact with each other; furthermore, both their direct actions and the extent of their interactions may change during development $[12,14-16,18,28,33,35]$. Thus differences between the adult and newborn in the relative release of these vasopressors in response to hypotension may not reflect differences in their importance in the maintenance of blood pressure.

During the period of hypotension, the heamtocrit of the newborn lamb decreased significantly by $2.5 \%$ then returned to control levels rather thirty minutes (table I). This change cannot be due to hemodilution due to volume loading since the volume infused never exceeded $6 \mathrm{ml}$. These results together with the absence of change in plasma osmolality agree with the conclusions of BRACE et al and Ross et al in the fetal lamb, that there is a transfer of iso-osmotic fluid from the interstitium to the intravascular space in response to hemorrhage or hypotension $[3,20]$.

In the adult, cessation of nitroprusside infusion resulted in a transient rebound hypertension which could be eliminated by propranolol, nephrectomy, or angiotensin converting enzyme inhibition $[1,19]$. These results suggested that the rebound hypertension was a function of release of catecholamines and activation of the renin angiotensin system although vasopressin might also have played an important role. In the present experiments on the newborn lamb, significantly elevated levels of renin and catecholamines were found during this period. The duration of hypertension (post nitroprusside infusion) in the newborn lamb was less than that observed in the fetal lamb [40] but longer than in the ewe [39]. These elevated values thirty minutes after the end of hypotension could be due to low rate of elimination as a result of prolonged effect of nitroprusside on mesenteric and renal blood flows $[20,30,38]$. In any case, these observations suggest that the ability of the newborn lamb to precisely regulate the release or metabolism of vasoactive mediators is between that of the fetal and adult sheep.

In summary, the newborn lamb responded to nitroprusside induced hypotension by releasing vasopressin, renin and catecholamines. The increase in plasma levels of vasopressin was smaller, while that of renin activity was larger and catecholamines similar to that found in the ewe. The duration of the rebound hypertension was longer than has been observed in fetal sheep. Concurrent with the hypertension, there were prolonged elevated levels of plasma renin activity and catecholamines. We speculate that these elevated levels of vasoactive mediators are responsible for the prolonged rebound hypertension and thus represent immaturity in the lamb's ability to regulate release or metabolism of these mediators. 


\begin{abstract}
The circulating levels of vasopressin, catecholamines and renin activity before, during and following a 10$20 \%$ fall in mean arterial blood pressure induced by sodium nitroprusside were measured in six chronically catheterized lambs during the first week of life.

No significant changes in $\mathrm{pHa}, \mathrm{PaO}_{2}, \mathrm{PaCO}_{2}$, Plasma sodium or osmolality were observed during or following the infusion of sodium nitroprusside at an average of $12 \mathrm{~g} \cdot \mathrm{kg}^{-1} \cdot \mathrm{min}^{-1}$ (table I). However, the fall in blood pressure at the end of 60 minutes infusion, was associated with significant increases in the plasma levels of vasopressin from a control value of $2.4 \pm 0.57$ to a maximum of $35.1 \pm 16.3 \mathrm{pg} / \mathrm{ml}(\mathrm{p}=.002)$, renin activity from $6.7 \pm 1.56$ to $27.4 \pm 11.44 \mathrm{ng} \cdot \mathrm{ml}^{-1}$ $\cdot \mathrm{hr}^{-1}(\mathrm{p}=.003)$, and catecholamines from 189.3 \pm 42.15 to $543.3 \pm 100.52 \mathrm{pg} \cdot \mathrm{ml}^{-1}(\mathrm{p}=.0001)$. The

increase in vasopressin is lower, while that of PRA was higher and catecholamines similar to those found in the ewe. Plasma renin activity (PRA) and catecholamine levels remained elevated for at least 30 minutes following the end of the infusion while the mean blood pressure rose significantly above control levels and remained elevated for twenty minutes (figures 1 and 2). We speculate that the persistent elevated levels of vasoactive mediators are responsible for the prolonged rebound hypertension following the cessation of the nitroprusside infusion and is the result of an immaturity of either a feedback process or metabolism of the vasoactive mediators or a combination of both mechanisms. This rebound hypertension could have adverse effects particularly in the very immature neonate.
\end{abstract}

Keywords: Catecholamines, hypotension, neonate, nitroprusside, plasma renin activity, vasopressin.

\section{Zusammenfassung}

Vasopressin, Renin und Catecholamine im Plasma während Nitroprussid-induzierter Hypotensionen beim neugeborenen Schaf

Vor, während und nach einem 10-20\%igen Abfall des mittleren arteriellen Blutdrucks, induziert durch Nitroprussid, bestimmten wir die Aktivität von Vasopressin, Catecholaminen und Renin bei 6 katheterisierten Schafen in der ersten Lebenswoche. Die mittlere Gesamtdosis an Nitroprussid, die zum Erreichen des gewünschten Blutdruckabfalls notwendig war, betrug $0.739 \pm 0.274 \mathrm{mg} / \mathrm{kg}$ bei Infusion über $60 \mathrm{~min}$ oder $12 \mathrm{~g} / \mathrm{kg} / \mathrm{min}$.

Wir beobachteten keine signifikanten Veränderungen des $\mathrm{pHa}, \mathrm{PaO}_{2}, \mathrm{PaCO}_{2}, \mathrm{Na}^{+}$-Wertes im Plasma und der Osmolalität während und nach einer NitroprussidInfusion von durchschnittlich $12 \mathrm{~g} / \mathrm{kg} / \mathrm{min}$ (Tab. I). Nach einer 60minütigen Infusion war jedoch der Blutdruckabfall assoziiert mit signifikanten Anstiegen der Plasmaspiegel von Vasopressin auf $35.1 \pm 16.3 \mathrm{pg} / \mathrm{ml}$ maximal gegenüber Kontrollwerten von $2.4 \pm 0.57 \mathrm{pg} /$ $\mathrm{ml}(\mathrm{p}=0.002)$, der Reninaktivität von $6.7 \pm 1.56$ auf $27.4 \pm 11.44 \mathrm{ng} / \mathrm{ml} / \mathrm{h}(\mathrm{p}=0.003)$ und der Catecholamine von $189.3 \pm 42.15$ auf $534.3 \pm 100.52 \mathrm{pg} / \mathrm{ml}$ $(p=0.001)$. Im Vergleich zum Muttertier war der Vasopressin-Anstieg geringer, der der PRa größer und der Anstieg der Catecholamine in derselben Größenordnung. Die Plasma-Renin-Aktivität (PRA) und die $\mathrm{Ca}$ techolamine blieben mindestens 30 min nach Ende der Infusion erhöht, während der mittlere Blutdruck signifikant über den Kontrollwerten lag und für $20 \mathrm{~min}$ erhöht blieb (Abb. 1 und 2).

Es könnte sein, daß persistierende erhöhte Spiegel an vasoaktiven Mediatoren verantwortlich sind für eine prolongierte Hypertension als Rebound-Effekt nach Ende der Nitroprussidinfusion. Dieses Phänomen mag durch eine Unreife des Feedback-Prozesses oder des Metabolismus der vasoaktiven Substanzen oder eine Kombination von beiden bedingt sein. Die ReboundHypertension könnte sehr ungünstige Auswirkungen, speziell beim sehr unreifen Neugeborenen haben.

Schlüsselwörter: Catecholamine, Hypotension, Neugeborenes, Nitroprussid, Plasmarenin-Aktivität, Vasporessin.

\section{Résumé}

Vasopressine, renine et catécholamines plasmatiques au cours de l'hypotension induite par le nitroprusside chez l'agneau nouveau-né

On a mesuré chez six agneaux cathétérisés de façon chronique au cours de la première semaine de vie, les tauxcirculants de Vasopressine, de Catécholamines et d'activité rénine avant et après une chute de $10.20 \%$ de la pression artérielle moyenne induite par le nitroprusside de sodium. La dose totale moyenne de nitroprusside necessaire pour obtenir le niveau souhaité d'hypotension a été de $0,739 \pm 0,274 \mathrm{mg} \cdot \mathrm{kg}^{-1}$ en perfusion pendant soixante minutes ou $12 \mathrm{~g} \cdot \mathrm{kg}^{-1}$ $\cdot \min$.

On n'a pas observé de modification significative du pHa, de la $\mathrm{Pa}$ o 2, de la $\mathrm{Pa}$ c o 2, du sodium plasmatique ni de l'osmolarité en cours ou après la perfusion de nitroprusside de sodium à la moyenne de $12 \mathrm{~g} \cdot \mathrm{kg}^{-1}$ - $\min ^{-1}$ (tableau I). Néanmoins, la baisse de la pression artérielle à la fin de la perfusion de 60 Minutes est associée de façon significative avec une élévation des taux plasmatiques de vasopressine depuis les valeurs contrôles de 2,4 $\pm 0,57$ jusqu'à umaximum de 35,1 
$\pm 16,3 \mathrm{pg} / \mathrm{ml}(\mathrm{p}=0,002)$, des taux plasmatiques d'activité rénine, de $6,7 \pm 1,56$ jusqu'à $27,4 \pm 11,44 \mathrm{ng}$ $\cdot \mathrm{ml}^{-1} \cdot \mathrm{hr}^{-1}(\mathrm{p}=0,003)$ et des taux plasmatiques de catécholamines de 189,3 $\pm 42,15$ jusqu'à $534,3 \pm \mathrm{pg}$ $\cdot \mathrm{ml}^{-1}(\mathrm{p}=0,0001)$.

L'élévation de la vasopressine est plus faible que les valeurs retrouvées chez la brebis alors que la PRA est plus élevée et les catécholamiens similaires. L'activité rénine plasmatique (PRA) et les taux de catécholamines demeurent élevés au moins 30 minutes après la fin de la perfusion alors que la pression sanguine moyenne s'élève de façon significative au-dessus des témoins et reste élevée pendant vingt minutes (fig. 1 et 2).

Nous émettons l'hypothèse que les taux élevés persistants de médiateurs vaso-actifs sont responsables du rebond hypertensif, prolongé qui suit l'arrêt de la perfusion de nitroprusside et que ce rebond est le résultat médiateurs vasoactifs ou d'une combinaison des 2 . Ce rebond hypertensif pourait entrainer des effets nuisibles tout particulièrement chez le nouveau-né très immature.

Mots-clés: Catécholamines, hypotension, nouveau-né, nitroprusside, activité rénine plasmatique, vasopressine.

Acknowledgements: Supported in part by grants HD 12737, HD 13063 and HL 14218 from the National Institutes of Health

\section{References}

[1] Abukhres MM, RJ Ertel, BN Dixit, RR VolMER: Role of the renin-angiotensin system in the blood pressure rebound to sodium nitroprusside in the conscious rat. Eur J Pharm 58 (1979) 247

[2 Bonjour JP, RL MALVIN: Stimulation of ADH release by the renin-angiotensin system. Am J Physiol 218 (1970) 1555

[3] BRACE RA: Fetal blood volume response to acute fetal hemorrhage. Circ Res 52 (1983) 730

[4] Broughton Pipkin F, SML KirkPatrick, ER LUMBERS, JC MoTT: Renin and angiotensin-like levels in foetal, newborn and adult sheep. J Physiol (Lond) 241 (1974) 575

[5] COHEN WR, GJ PIASECKI, BT JACKson: Plasma catecholamines during hypoxemia in fetal lamb. Am J Physiol 243 (1982) R520

[6] Daniel SS, RI Stark, MK Husain, LV BaXI, LS JAMES: Role of vasopressin in fetal homeostasis. Am J Physiol 242 (1982) F740

[7] Daniel SS, RI Stark, AB Zubrow, HE Fox, MK HUSAIN, LS JAMES: Factors in the release of vasopressin by the hypoxic fetus. Endocrinol 113 (1983) 1623

[8] De Vane GU, RP Naden, JC Porter, CR RosenFELD: Mechanism of arginine vasopressin release in the sheep fetus. Pediatr Res 16 (1982) 504

[9] Gavras H, Hatzinikolaou, WG North, M BRESNAHAN, I Gavras: Interaction of the sympathetic nervous system with vasopressin and renin in the maintenance of blood pressure. Hypertension 4 (1982) 400

[10] Gomez RA, JG MeERNIK, WD KueHL, JE RobILLARD: Developmental aspects of the renal response to hemorrhage during fetal life. Pediatr Res 18 (1984) 20

[11] Granger P, JM Rojho-Ortega, SC Perez, R BOUCHER, J GENEST: The renin-angiotensin system in newborn dogs. Can J Physiol Pharm 49 (1971) 134
[12] Husain MK, N Fernando, M Shapiro, A KaGAN, SM GLICK: Radioimmunoassay of arginine vasopressin in human plasma. J Clin Endocrinol Metab 37 (1973) 616

[13] IWAMOTA HS, AM RUDOLPH: Role of renin-angiotensin system in response to hemmorrhage in fetal sheep. Am J Physiol 240 (1981) H 848

[14] JoHNSON JA, JO DAVIS, RT WITTY: Effects of catecholamines and renal nerve stimulation on renin release in the nonfiltering kidney. Circ Res 29 (1971) 646

[15] JOHnson MD, DN SHIER, AC BARGER: Circulating catecholamines and control of plasma renin activity in conscious dogs. Am J Physiol 236 (1979) $\mathrm{H} 463$

[16] Jones CM, JC Rose, RT Kelly, BY HaRgRaVe: Catecholamine responses in fetal lambs subjected to hemorrhage. Am H Obstet Gynecol 154 (1985) 475

[17] JONES CT, JWK RITCHIE: The cardiovascular effects of circulating catecholamines in fetal sheep. J Physiol 285 (1978) 381

[18] Kelly RT, JC Rose, PJ Meis, BY Hargrave, M MORRIS: Vasopressin is important for restoring cardiovascular homeostasis in fetal lambs subjected to hemorrhage. Am J Obstet Gynecol 146 (1983) 807

[19] Khambatta HJ, JG Stone, E Khan: Hypertension during anesthesia on discontinuation of sodium nitroprusside-induced hypotension. Anesthesiology 51 (1979) 127

[20] Kuipers JRG, D Sidi, MA Heymann, AM RuDOLPH: Effects of nitroprusside on cardiac function, blood flow distribution, and oxygen consumption in the conscious young lamb. Pediatr Res 18 (1984) 618

[21] Leake RD, RE Weitzman, JA Weinberg, DA FISHER: Control of vasopressin secretion in the newborn lamb. Ped Res 13 (1979) 257 
[22] Miller ED, JA Ackerly, D Vaughan, MJ PEACH, RM EPSTEIN: The renin-angiotensin system during controlled hypotension with sodium nitroprusside. Anesthiol 47 (1977) 257

[23] Montani JP, JF Liard, J Schoun, J Mohring: Hemodynamic effects of exogenous and endogenous vasopressin at low plasma concentrations in conscious dogs. Circ Res 47 (1980) 346

[24] MoLL JC: The place of the renin-angiotensins system before and after birth. Br Med Bull 31 (1975) 44

[25] Passon PA, JD Peuler: A simplified radiometric assay for plasma norepinephrine and epinephrine. Anals Biochem 51 (1973) 618

[26] Robillard JE, RE Weitzman, L Burmeister, FG SMITH, JR: Developmental aspects of he renal response to hypoxemia in the lamb fetus. Circ Res 48 (1981) 128

[27] Rose JC, M MorRIS, PJ MeIS: Developmental aspects of pituitary and adrenal responses to arterial hypotension in neonatal, weanling and adult sheep. Am J Physiol 242 (Endocrinol Metab) (1982) E215

[28] Rose JC, CM Jones, RT Kelly, BY Hargrave, PJ MEIS: A vasopressin antagonist blocks the norepinephrine and epinephrine responses to hemorrhage in the fetus. Endocrinol 113 (1983) 2314

[29] Rose JC, SM Block, K Flowe, M Morris, S SOUTH, DK SUNDBERG, C ZIMMERMAN: Responses to converting-enzyme inhibition and hemorrhage in newborn lambs and adult sheep. Am J Physiol 252 (1987) R306

[30] Ross MG, MG ERvin, RD Leake, O Habeeb, DA FISCHER: Isovolemic hypotension in ovine fetus: Plasma arginine vasopressin response and urinary effects. Am J Physiol 250 (1986) E564

[31] RudD P, TF BLASCHKEE: Antihypertensive agents and the drug therapy of hypertension. In: Gilman, $A G, L S$ Goodman, TW Rall, F Murad (eds): The pharmacological Basis of Therapeutics. Macmillan, New York 1985
[32] RURAK DW: Plasma vasopressin levels during hypoxaemia and the cardiovascular effects of exogenous vasopressin in foetal and adult sheep. $J$ Physiol (Lond) 277 (1978) 341

[33] SCHWARTZ J, IA REID: Effect of vasopressin blockade on blood pressure regulation during hemorrhage in conscious dogs. Endocrinol 109 (1981) 1778

[34] Sealey JE, JH LaRagh: Radioimmunoassay of plasma renin activity. Sem Nucl Med 5 (1975) 189

[35] Siegel SR, RE Weitzman, DA Fischer: Endogenous angiotensin stimulation of vasopressin in the newborn lamb. J Clin Invest 63 (1979) 287

[36] Stark RI, SS Daniel, MK Husain, UM SANOCKA, AB ZUBROW, LS JAMES: Vasopressin concentration in amniotic fluid as an index of fetal hypoxia: mechanism of release in sheep. Ped Res 18 (1984) 552

[37] TINKER JH, JD MichENFELDER: Sodium nitroprusside: Pharmacology, toxicology and therapeutics. Anesthesiol 45 (1976) 340

[38] WANG HH, LMP LIU, RL KATZ: A comparison of the cardiovascular effects of sodium nitroprusside and trimethaphan. Anesthesiol 46 (1977) 46

[39] Zubrow AB, SS DANIEL, RI STARK, MK HuSAIN, LS JAMES: Plasma renin, catecholamine, and vasopressin during nitroprusside-induced hypotension in ewes. Anesthesiology 58 (1983) 245

[40] Zubrow AB, S Daniel, R Stark, K Husain, LS JAMES: Plasma vasopressin, renin and catecholamines during nitroprusside-induced maternal and fetal hypotension in sheep. Ped Res 24 (1988) 73

Received December 23, 1988. Accepted January 22, 1989.

Alan B. Zubrow, M. D.

The Medical College of Pediatrics

3300 Henry Avenue

Philadelphia, PA 19129, U.S. A. 